\title{
Resumiendo Hipnosis y Cirugía
}

\author{
Raúl Llanos MD* \\ Se incluye el caso de una paciente que \\ tuvo una cesárea bajo hipnoanestesia
}

La señora P.C. tenía 21 años cuando aprendió algunas técnicas de relajamiento durante el cuidado de su embarazo. Previamente había tenido una cesárea y también como consecuencia de su habilidad para aprender a relajarse, se interesó por tener su bebé bajo hipnoanestesia.

Mientras estaba en trance, aprendió diferentes técnicas para ser utilizadas con su cesárea, incluyendo la creación de su propia anestesia, distorsión del tiempo y disociación. Un ensayo también se llevó a cabo unos días an tes de la cesárea en la sala de cirugía donde iba a tener su cirugía. Exitosamente tuvo su bebé a término bajo hipnoanestesia y se recuperó muy bien después del parto. Nunca necesitó medicamentos para el dolor u otra clase de medicinas después de la cirugía. Fue dada de alta al tercer día después de la cesárea aunque ella quiso irse antes.

El tema de la hipnosis y cirugía tiene diferentes ramificaciones. Comoúnico me-

* Profesor Asistente de Clinica. TULANE ME.

DICAL SCHOOL - OB/GYN

DEPARTMENT. dio de anestesia, ha sido descrito en la literatura en cualquier clase de procedimiento quirúrgico incluyendo los informes de Esdaile de más de 3.000 casos. Durante el tiempo de cirugía los pacientes entran en un trance profundo usando diferentes técnicas durante las cuales las funciones fisiológicas, incluyendo el pulso, la respiración y la presión arterial pueden variar, pero en general, permanecen muy estables. Durante la cirugía también es muy llamativo ver la hemostasis que automáticamente se presenta como una forma de protección. La recuperación se hace más rápidamente y como sucedió en esta paciente, la cantidad de narcóticos $u$ otra clase de medicina se reducen al mínimo.

La hipnosis ha sido usada también como una manera de preparar el paciente para cirugía cuando anestesia general o bloqueo regional son utilizados. Antes de la cirugía el paciente tiene un ensayo mental de su cirugía; recibe sugerencias y también se proyecta en el futuro, incluyendo el día cuando él está completamente recuperado. En estos casos se ha encontrado que el paciente llega a ser menos dependiente, más responsable por su salud y la cantidad de medicinas que recibe para el 
dolor, para las náuseas o para dormir son significativamente reducidas. La recuperación se acelera y el paciente se siente más confortable.

Con el uso de la hipnosis también hemos podido entender más acerca de lo que implica para el paciente los eventos que están sucediendo cuando él está bajo anestesia general. Es bien sabido que en trance el paciente es capaz de recordar aquella parte de la cirugía que tuvo un significado especial. Quejas y actitudes incómodas pueden haber tenido su origen en la forma literal como la mente subconciente percibió el estímulo mientras estaba bajo el efecto de la anestesia. Ayudándole al paciente a regresar a ese momento de su cirugía, él puede darle un nuevo significado al estímulo y como consecuencia mejorarse de sus dolores o de su actitud incómoda. El entender que el paciente es capaz de recibir información mientras está bajo el efecto de la anestesia general nos provee de nuevos medios para prepararlo y también poder ayudar a que el personal de cirugía esté más conciente de todas estas posibilidades. El paciente se puede beneficiar de este conocimiento a traveś de sugerencias en las cuales le hablamos en forma directa mientras está en cirugía o mediante cintas magnetofónicas, con el fin de proveer al subconciente de ese enfermo de la información que necesita para obtener mejores resultados.

En las urgencias médicas la hipnosis se puede utilizar en forma muy eficiente, especialmente porque estos pacientes están muy motivados. En ellos existe una necesidad inmediata del tratamiento. En la literatura existen informes sobre reducciones de hombro y fracturas; sutura de dehiscencias y muchos otros procedimientos quirúrgicos en donde la única forma de anestesia o de relajamiento fue la obte- nida mediante las sugerencias dadas al paciente cuando estaba en trance.

La Hipnosis también ha sido utilizada para tratar distrofia simpática; para obtener la anestesia necesaria para remover verrugas o simplemente para ayudarle al paciente a que se deshaga de ellas. En cirugía plástica la hipnosis ha sido utilizada para ayudarle a los pacientes a mantenerse en posiciones incómodas cuando el trasplante lo requiere.

En oftalmología y en otras especialidades y en diferentes procedimientos el uso de hipnosis ha sido descrito ampliamente en la literatura. La hipnosis ha sido utilizada en los quemados con el fin de limitar la reacción inflamatoria y por consiguiente el daño a los tejidos. Brauer y Spira (1966) demostraron que el daño de las capas profundas de la piel generalmente son secundarias a la inflamación y no al calor.

Las complicaciones en cirugía, incluyendo infecciones, sangrado y fenómenos tromboembólicos pueden ser reducidas con el uso de hipnosis. Porque en las series de Esdaile (1947) la mortalidad por infección bajó del 45 al 5\% cuando él empezó a usar hipnoanestesia. Shafer (1975) notó que los pacientes de la unidad de quemados que fueron hipnotizados cicatrizaron sin infección. De Takats (1944) informó la disminución en el tiempo de la formación de coágulo como consecuencia del miedo antes de la cirugía. Schneider (1951) estudió seis pacientes con flebitis recurrente en quienes el tiempo de coagulación estaba marcadamente disminuido a consecuencia del stress. Yudine (1937) observó que la sangre del cadáver de personas que morían en pánico no coagulaba (fibrinolisis) y usó esta sangre en más de 100 transfusiones antes de que los bancos de sangre fueran establecidos. 
En contraste, ella describió que aquellas personas que mueren lentamente por cáncer o tuberculosis, su sangre coagulaba y no se disolvía.

La hipnosis es otra herramienta que nosotros los médicos tenemos dentro de nuestro armamentario para ayudar a que el paciente se recupere. Aunque el uso de hipnosis en cirugía no es el de remplazar los métodos convencionales de anestesia, si nos da una brillante oportunidad para entender cómo podemos programarnos mejor para prestar un mejor servicio $y$ también como podemos ayudarle al paciente en su propia programación.

El paciente se recupera mejor y es capaz de volver a sus actividades normales con una mejor confianza en sí mismo.

\section{SUMMARY}

A case where a patient had her baby through a Cesarean Section under hypnoanesthesea is presented. Also, a review of the use of hypnosis in surgery is described. Hypnosis is a very important tool that we can use on the patients and on ourselves to enhance the results of surgery.

\section{BIBLIOGRAFIA}

LLANOS, R.: The Use of Hypnosis in Obstetric \& Gynecology. Journal LA State Medical Society, Vol. 137, 11:35-38, 1985.

LLANOS, R. BOHM, J: Hipnosis en el tratamiento del Cáncer. Revista Colombiana de OB/GIN, Vol. 36, 5: 333-336, 1985.

LLANOS, R.: Natural Delivery. National Library of the American Society of Clinical Hypnosis, Video Tape, 1985.

LLANOS, R: Cesarean Section Under Hypnoanesthesia. National Library of the American Society of Clinical Hypnosis, Video Tape, 1985.

LLANOS, R.: Minor Gynecological Procedures Under Hypnoanesthesia. National Library of the American Society of Clinical Hypnosis, Video Tape, 1985.

ABRAMSON, M.: Self-Hypnosis for hemophiliacs. Present at the American Society of Clinical Hypnosis Workshop, University of Minnesota, October 7, 1970.

ABRAMSON, M. GREENFIELD, I. HERON, WT: Response to or perception of auditory stimuli under deep surgical anesthesia. Am J Obstet Gynecol 96: 584, 1966.

AGLE, DP., RATNOFF, OD: Purpura as psychosomatic entity. Arch Intern Med 109: 685, 1962.

BENSEN, VB: One hundred cases of postanesthetic suggestion in the recovery room. Am J Clin Hypn 13: 273, 1971.

BRAUER, RO, SPIRA, M.: Full thickness burns as source for donor graft in the pig. Plast Recons Surgery 37: 31, 1966.

BRUNN, JT. The capacity to hear, understand and to remember experiences during chemo-anesthesia: A personal experience. Am. J. Clin Hypn 6: 27, 1963.

CANNON, WB, GRAY, H.: Factors affecting the coagulation of blood. II The hastening of retarding of coagulation by adrenalin injections. Am J Physiol 34: 232, 1914.

CANNON, WB, MENDENHALL, WL.: Factors affecting the coagulation time of blood. IV The hastening of coagulation in pain and emotional excitement. Am J Physiol 34: 251, 1914. 
CHEEK, DB: Unconscious perception of meaningful sounds during surgical anesthesia as revealed under hypnosis. Am $\mathrm{J}$ Clin Hypn 1: 101, 1959.

CHEEK, DB: Removal of subconscious resistance to hypnosis using ideomotor questioning techniques. Am J Clin Hypn 3: 103, 1960.

CHEEK, DB: Areas of research into psychomatic aspects of surgical tragedies now open through use of hypnoss and ideomotor questioning. West J Surg Ob Gyn 70: 137, 1962.

CHEEK, DB:Importance of recognizing that surgical patients behave as though hypnotized. Am J. Clin Hypn 4: 277, 1962.

CHEEK, DB: Ideomotor questioning for investigation of subconscious "pain" and target organ vulnerability. Am J Clin Hypn 5:30, 1962.

CHEEK, DB: Physiological impact of fear in dreams: postoperative hemorrhage. Am J Clim Hypn 5: 206, 1963.

CHEEK, DB: Surgical memory and reaction to careless conversation. Am $\mathrm{J}$ Clin Hypn 6: 237, 1964.

CHEEK, DB: Furtier evidence of persistence of hearing under chemoanesthesia: Detailed case report. Am J Clin Hypn 7:55, 1964.

CHEEK, DB: Communication with the critically ill. Am J Clin Hypn 12: 75, 69.

CHEEK, DB: Awareness of meaningful sounds under general anesthesia: Considerations and a review of the literature 1959-1979. In Wain, HJ (ed): Theoretical and Clinical Aspects of hypnosis, p. 87, Miami, Symposia Specialists, 1981.

DeTAKATS, G.: Nervous regulation of clotting mechanism. Arch Surg 48: 105, 1944.
DUBIN, LL. SHAPIRO, SS: Use of hypnosis to facilitate dental extraction and hemostasis in a classic hemophiliac with a high antibody titer to factor VIII. Am J Clin Hypn 17: $79,1974$.

ESDAILE, J: Hypnosis in Medicine and Surgery New York, Julian Press, 1957.

EWiN, DM: A case of reflex sympathetic dystrophy of the left hand cured by hypnosis. Presented at the 17th Annual Meeting of the American Society of Clinical Hypnosis, New Orleans, 1974.

EWIN, DM: Clinical use of hypnosis for attenuation of burn depth. In Frankel, FH, Zamansky, HS: Hypnosis at its BicentennialSelected Papers from the Seventh International Congress of Hypnosis and Psychosomatic Medicine. New York, Plenum Press, 1978.

EWIN, DM: Hypnosis in burn theraphy. In Burrows, GD, Collison, DR, Dennerstein, L (eds): Hypnosis 1979. Elsevier/North HoIland Press, 1979.

EWIN, DM: Constant pain syndrome: Its psychological meaning and care using hypnoanalysis. In Wain, HJ (ed); Clinical Hypnosis in Medicine. Chicago, Year Book Medical Publishers, 1980.

EWIN, DM, HILL, FE: Analytical hypnotherapy of recurrent herpes genitalis; Report of four cases. Present at the 24th Annual Meeting of the American Society of Clinical Hypnosis, Boston, November 14, 1981.

MAGAW, A: A review of over fourteen thousand surgical anesthesias. Surg Gyn Obst 3: 795, 1906.

SCHAFER, DW: Hypnosis use on a burn unit. Int J Clin Exp Hypn 23: 1, 1975. 
SCHNEIDER RA: Recurrent thrombophlebitis an experimental study of life situations and emotions and clotting time and relative viscosity of the blood. Am J Med Sci 222: 562, 1951.

ULLMAN, M: Herpes simplex and second degree burn induced under hypnosis. Am J Psychiatry 103: 828, 1947.
WOLFE, LA, MILLETT, J: Control of postoperative pain by suggestion under general anesthesia. Am J Clin Hypn 3:109, 1960.

YUDINE, SS: Transfusion of stored cadaver blood. Lancet 2: 360, 1937. 